\title{
GREEN ROOF PLANT RESPONSES TO GREYWATER IRRIGATION
}

\author{
YALÇINALP, E. ${ }^{1}-$ ŞIVIL, M. ${ }^{1}-$ MERAL, A. $.^{2 *}-$ DEMIR, Y. ${ }^{3}$ \\ ${ }^{I}$ Department of Landscape Architecture, Faculty of Forestry, Karadeniz Technical University \\ 61080, Trabzon, Turkey \\ (phone: +90-462-377-4050; fax: +90-462-235-3205) \\ ${ }^{2}$ Department of Landscape Architecture, Faculty of Agriculture, Bingol University \\ 12000, Bingol, Turkey \\ (phone: +90-426-216-0012; fax: +90-426-216-0029) \\ ${ }^{3}$ Department of Soil Science and Plant Nutrition, Faculty of Agriculture, Bingol University \\ 12000, Bingol, Turkey \\ (phone: +90-426-216-0012; fax: +90-426-216-0029) \\ *Corresponding author \\ e-mail: alperenmeral@bingol.edu.tr; phone: +90-426-216-0012; fax: +90-426-216-0029 \\ (Received 20 $0^{\text {th }}$ Dec 2018; accepted $26^{\text {th }}$ Feb 2019)
}

\begin{abstract}
Water is an essential natural resource and is even known to be the cause of many wars of history. While people depend on it to survive, they also use it for everyday activities and several other purposes. As for plants, water is an essential factor, one they need for growth. Although irrigation is really important for certain agricultural plants, many criticise its water consumption especially on scientific platforms and media. This naturally pushes the world to find alternative ways to decrease the water consumption where possible. Greywater (GW) use is one of these alternative ways. This study aims to focus on two different but ecologically useful recent phenomena; GW use and green roofs. GW use makes it possible to decrease water consumption by replacing irrigation water, while green roofs (GRs) are known to increase biodiversity in urban areas and to decrease heat island effect and as a result reduce the costs of air conditioning. Since the main purposes of this study are to evaluate the use of GW on GRs to examine if there might be an ecologically and economically more beneficial way to keep the roof green, we used a prepared greywater simulation (PGWS) to measure green roof plants' responses to it. Two different greywater models, non-diluted prepared greywater simulation (N-D.PGSW) and 50\% diluted prepared greywater simulation (\%50-D.PGWS), were used for irrigation; while tap water (TW) irrigation and no irrigation (N-I) were the other two conditions to make the study more reliable.
\end{abstract}

Keywords: Sedum irrigation, urban landscape, water management, environmental management, sustainable water use

\section{Introduction}

Water is a life-sustaining natural resource and has been regarded as inexhaustible until quite recently, but the accelerating population growth and development of industrial activities have led to its depletion, especially in areas facing drought (Illan, 2011). After the recognition of water as an exhaustible resource, innovative technological and agronomic practices such as storage and regulation methods for water, installation of irrigation automation systems, and reuse of wastewater were adopted. Despite these innovations and cultural practices, cities currently suffer from water deficit. Water deficit is defined as the exceedance of the currently-available renewable sources by the sum of the water use requirement of different fields (urban, agricultural, industrial, and environmental uses) (Zavala and Estrada, 2016). 
GW is defined as the urban wastewater consisting of the waters used for domestic purposes except for the toilet water (water from bathroom sink, shower, lavatory, dishwasher, washing machine, and kitchen) (Mohamed et al., 2013; Li et al., 2009; Ottoson and Stenströn, 2003; Eriksson, 2002; Jefferson et al., 1999). GW constitutes 50$80 \%$ of the total wastewater use of a household (Antonopoulou, 2013; Friedler and Hadari, 2006; Eriksson et al., 2003). Previous studies reported that depending on the population structure, tradition and habits, structure of the plumbing system, and water abundance, the use of GW vary between $90-120 \mathrm{l} / \mathrm{p} / \mathrm{d}$ (liter/person/day) in developed countries, whereas in low-income and water-scarce countries the rate drops to $20-30 \mathrm{l} / \mathrm{p} / \mathrm{d}$ (Morel and Diener, 2006).

In addition to avoiding river pollution, the use of $\mathrm{GW}$ as a valuable fertilizer and for irrigation purposes in landscape and agricultural areas in Rome, Greece, China, England, and Germany dates back to ancient times. The use of wastewaters in irrigation has emerged as an effective mechanism to regulate water resources in water-scarce areas since the 16th century (Zavala, 2016; Negahban-Azar et al., 2012).

One of the main factors adding to the importance of GW is undoubtfully the expanding place of its generators in everyday use. In addition, since GW do not contain fecal waters, they can be easily treated and potentially reused (Yalçınalp et al., 2018). Moreover, GW is increasingly used due to the lower polluting effects of pathogens and nitrogen ( $\mathrm{Li}$ et al., 2009; Li et al, 2003). The use of GW in gardens, car washing, laundries, and toilet flushes has been a long-employed practice in various regions of the world. The use of treated GW also greatly contribute to the protection of high-quality water resources. Depending on the popularization of these practices, this contribution brings along a great cumulative potential as well ( $\mathrm{Li}$ et al., 2003).

It is clear that the reuse of waste water poses a health risk both for the public and system employees due to the high exposure rate to pathogenic microorganisms and toxic materials. The health concerns regarding the increases in these activities generally involve the extent of human exposure to treated wastewater, the type and quality of the treated wastewater, and the safety of the treatment processes (Zavala and Estrada, 2016; Benami et al., 2013). Nonetheless, in the case of landscape plants, since they are not edible and thus, the water used in their irrigation can have a lower microbiological quality, the use of wastewaters is advantageous in the irrigation of landscape plants.

The great amounts of the GW generated by the recent large-scale urban development in Trabzon have led to its emergence as a new recyclable water resource. GW will be an important resource to partially mitigate the water deficiency and prevent the pollution of environment by these waters.

Despite its huge popularity in recent years due to its great potential and the environmentally destructive course of the world, pessimistic and refraining voices have been raised against the use of GW. The most prominent concern is the doubts about its possible use in the irrigation of edible plants. Furthermore, the possibility and rapidity of bacterial growth during the storage of $\mathrm{GW}$, which contains bacterial growth-facilitating organic wastes, have long been among the underlying causes of the reluctance towards its use. However, scientific studies evaluating it within the limits of universal standards have indicated that GW was a safe and sustainable resource.

Analysis of the detailed information gleaned in this study helps (1) to evaluate green roof plants' response to GW irrigation, (2) to make a contribution to green roof phenomena by decreasing the estimated irrigation costs in the long term as GW has a huge potential to take tap water place for irrigation and maybe the most importantly (3) 
to create a more sustainable green roof approach to prevent water waste while green roof is already considered as an ecological way to make urban areas healthier and more livable.

\section{Material and Method}

\section{Study area}

The roof of the Landscape Architecture Department of the Karadeniz Technical University $\left(40^{\circ} 59^{\prime} 27.02^{\prime \prime} \mathrm{N}, 39^{\circ} 46^{\prime} 30.80^{\prime \prime} \mathrm{E}\right)$ was selected as the study area (Figure 1). After obtaining the necessary permissions, the materials were transferred to the roof using a crane installed on the rooftop and the irrigation equipment were prepared for use. The city covers an area of approximately $4.685 \mathrm{~km} 2$ and has a population of about 758.237 inhabitants, making it the second largest principal city in the region (Anonymous, 2013a). The city is within the A8 of the grid system created by Davis 1965 and Davis 1985 and the annual mean rainfall is about $760 \mathrm{~mm}$, while the mean temperature is about $14.6^{\circ} \mathrm{C}$. The monthly mean temperature ranges from $7.3{ }^{\circ} \mathrm{C}$ in January and from 13 to $23.1{ }^{\circ} \mathrm{C}$ in August.

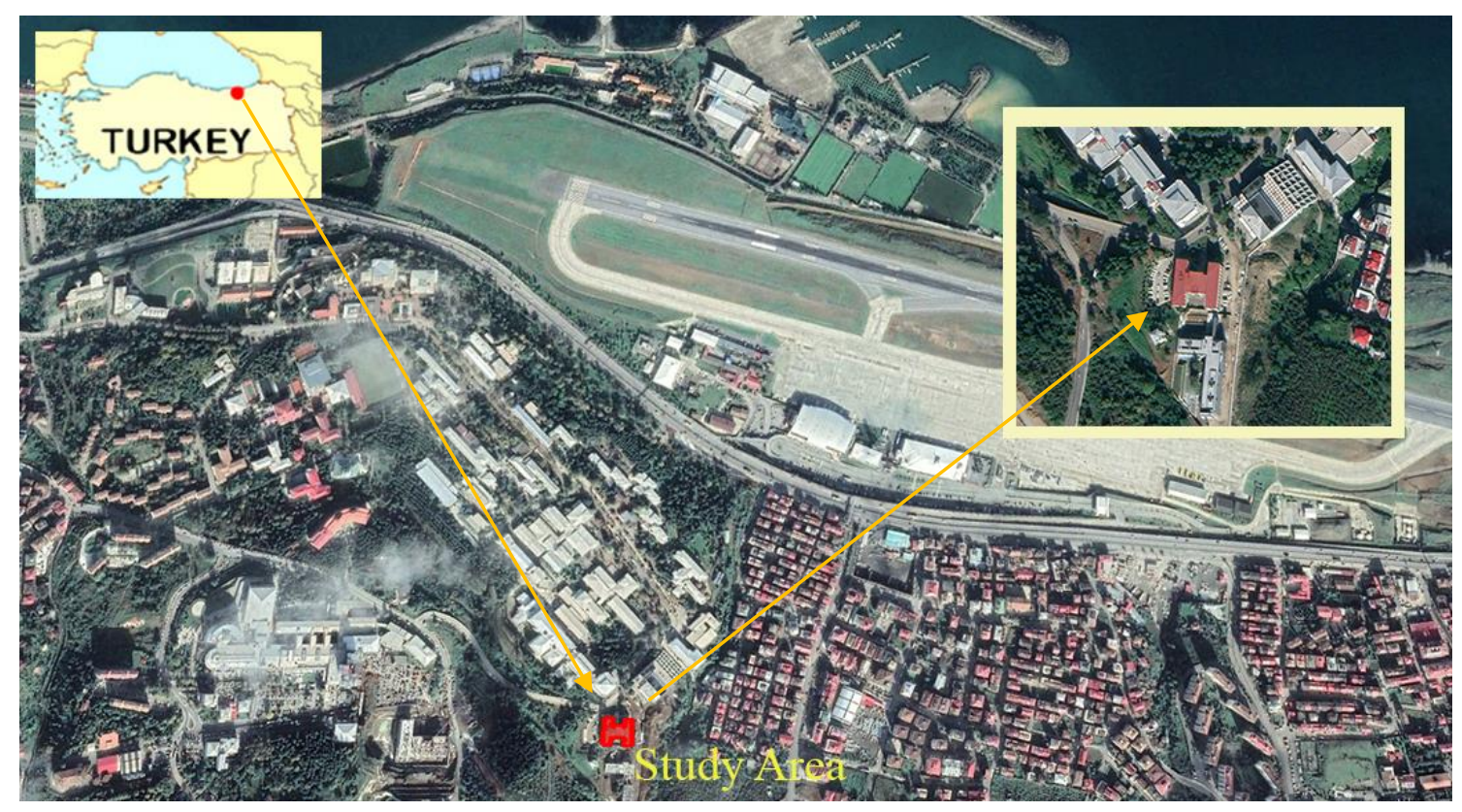

Figure 1. Study area

\section{The Installation of the Experiment}

A review of the relevant literature revealed that Sedum species were used in various studies on GRs. Sedum album and Sedum sediforme, as two species from one of the genera that first come to mind when GRs are considered, were used as the plant materials in this study as well. Sedum album and Sedum sediforme plants that were brought to the study area, derived from the same origin, and as identical as possible were planted in $60 \mathrm{~cm} \times 40 \mathrm{~cm}$ pots and on $10 \mathrm{~cm}$ blockage for drainage and $20 \mathrm{~cm}$ soil. To obtain data for the comparisons, experiments were installed in a total of 80 pots comprising 10 pots for each Sedum species and each irrigation type (N-I, TW, 50\%-D.PGWS, N-D.PGWS). The irrigation rate was planned to be $1 \mathrm{~L} / \mathrm{w}$ (Liter/Week) for each pot. The plants were planted 
in the middle of the pots in an area of $24 \mathrm{~cm} 2$ (about $10 \%$ of the total area) to achieve the adequate examination of the plant propagation. According to the monthly precipitation reports of the Trabzon General Directorate of Meteorology for 2016-2017, during the experiment, the plants were exposed to a monthly precipitation ranging from $6.3 \mathrm{~mm}$ to $160.2 \mathrm{~mm}$ and corresponding to an annual precipitation of $88.37 \mathrm{~mm}$.

The plant and soil samples were prepared for analyses at the end of the experiment in December 2017 by collecting and blending the samples from each pot that contain plants from the 8 groups examined using different irrigation systems. Soil samples were randomly taken in a depth of approximately $0-15 \mathrm{~cm}$ from an open-air field in a nursery. Then the samples were dried at $110{ }^{\circ} \mathrm{C}$ and transferred to polyethylene bags until the installation. To make sure that each pot will have the same amount of soil, a bascule was used just before putting the soil into the pots. Trying to pick similar in size, plant samples in 2 different Sedum species were also taken from the same nursery and kept on the roof top for the last 3 days to the installation.

Because one of the main aims of the study is to make a practical, sustainable and significant contribution to the green roof existence apart from the evaluating of the plants' responses to greywater, periodic watering was chosen as the irrigation method just like how it is done in the traditional gardening in the area to simulate the conditions on the roof top as close as possible to the daily life.

\section{The Preparation of the Greywater Simulation}

The daily water use in Turkey is $216 \mathrm{~L} / \mathrm{p} / \mathrm{d}$ (liter/person/day), whereas the daily water use in Trabzon, Turkey, was determined to be $333 \mathrm{~L} / \mathrm{p} / \mathrm{d}$ (Anonymous, 2013b). No reliable data concerning the average consumption of the chemicals involved in the formation of GW in Turkey were found. Thus, developing an average model for GW has emerged as one of the most important steps of the study. For the simulation of average GW, a "Household greywater scenario" (HGWS) that can provide an insight into the average consumption levels was constructed by combining statistical data such as the average number of individuals in a household and empirical data such as hand washing, teeth brushing, shaving, etc. By grouping the activities such as bathing, cleaning, and personal care, etc. according to the scenario, we were able to derive estimates about the weekly frequency of the activities and by whom the activities were performed, the amount of shampoo, detergent, and cleaning product use, and the contents of the greywater generated by water use. According to the simulation, the amounts of the materials in $1 \mathrm{~L}$ GW generated within the scope of the study are given below (Table 1).

The cleaning products were randomly procured from a grocery at the city center and during the study, same products were used in the same amounts. The storage of GW is one of the most important issues in industrial $\mathrm{GW}$ use, the main reason being the emergence of a bacterial growth-facilitating habitat during the storage due to the organic wastes in its content. To evade this problem, GW was not stored in the study and instead, a new HGWS was created using measuring cups before each irrigation. Attention was given to the complete dissolution of each material added to the HGWS and continuous stirring was applied; then, the GW was rested for an hour, followed by it use for irrigation. Although not using storage for the GW used in irrigation may seem like a disadvantage in terms of the accurate representation of the standard case, this concern is minimized by the currently present measures taken against the bacterial growth in the GW generated by the use of industrial products. 
Table 1. The amounts of the materials in non-diluted and half-diluted greywaters

\begin{tabular}{l|c|c}
\hline & N-D.PGWS & 50\%-D.PGWS \\
\hline Shampoo & $0,077 \mathrm{ml} / 1$ & $0,038 \mathrm{ml} / 1$ \\
Shower gel & $0,038 \mathrm{ml} / 1$ & $0,019 \mathrm{ml} / 1$ \\
Liquid soap & $0,225 \mathrm{ml} / 1$ & $0,113 \mathrm{ml} / 1$ \\
Toothpaste & $0,027 \mathrm{ml} / 1$ & $0,014 \mathrm{ml} / 1$ \\
Dish soap & $0,135 \mathrm{ml} / 1$ & $0,068 \mathrm{ml} / 1$ \\
Surface cleaner & $0,027 \mathrm{ml} / 1$ & $0,014 \mathrm{ml} / 1$ \\
Glass cleaner & $0,233 \mathrm{ml} / 1$ & $0,117 \mathrm{ml} / 1$ \\
Shaving foam & $0,167 \mathrm{ml} / 1$ & $0,083 \mathrm{ml} / 1$ \\
Bleach & $0,013 \mathrm{ml} / 1$ & $0,007 \mathrm{ml} / 1$ \\
Detergent & $0,750 \mathrm{~g} / 1$ & $0,375 \mathrm{~g} / 1$ \\
\hline
\end{tabular}

In the study, a group of plants was not irrigated and left by themselves after installation, while the other groups were irrigated for two years from March 2015 to March 2017 in every Saturday when no rainfall had occurred. For irrigation, $1 \mathrm{~L}$ water was used for each case containing the plants and drip irrigation was preferred. The HGWS was directly applied to one plant group, while the other group received 50\%-D.PGWS and the final group directly received TW.

In addition to the irrigation with the GW, all samples were exposed to natural rainwater. Although this may raise a doubt about the accurate uncovering of the relationship between GW and the two Sedum species examined in the GR, since the main concern of the study is the performance of GW in GRs and GRs are already exposed to rainwater, this issue is believed to enhance the ability of the study to reflect the realities of practice. In addition, as all cases containing the plants were exposed to rainfall, the effect of precipitation on GW-plant relationship, if there is any, most certainly takes place under the same conditions as each plant.

\section{The Analyses of Soil, Water and Plants}

To determine the plant propagation rate at the end of the two-year experiment in the pots, separate photographs of each pot from each group were taken $1 \mathrm{~m}$ above the intersection of the diagonals and prepared for examination in an office setting. Each photograph was divided into $5 \mathrm{~cm} \times 5 \mathrm{~cm}$ grids in the computer environment and the Sedum cover for each pot was established by determining the frames containing the Sedum species. The growth of wild weeds both through the soil in which the experiment was installed and through pollination was also observed in the experimental areas during the vegetation period. Weeding was not carried out to observe the competition between the Sedum species and wild weeds.

Then, the plant samples were pressed and dried between blotting papers and prepared for identification. The dried and identified plants were then ground in a plant grinding mill and the wet digestion method was employed using $\mathrm{HNO}_{3}$ to prepare the samples for analysis. The soil samples were laid and dried on blotting papers for one week and the 
blotting papers were replaced three times during this period. Upon drying, the soil was prepared for analysis after sieving with a $2 \mathrm{~mm}$ sieve.

The heavy metal ratios in the plant, soil, and water samples prepared for analyses were determined and entered in the database using the atomic absorption device of the Research and Application Center of the Central Laboratory of Bingol University. As the same water samples were used for N-D.PGWS and 50\%-D.PGWS, water analysis was not separately performed for the each group.

All parameters (soil particle size; $\mathrm{pH}$; EC; organic matter; $\mathrm{CaCO}_{3}, \mathrm{Fe}, \mathrm{Zn}, \mathrm{Cu}, \mathrm{Mn}, \mathrm{Cr}$, $\mathrm{Ni}$, and $\mathrm{Pb}$ contents) were determined by common methods used in practice. The particle size analysis was done using standard hydrometer method described by Gee and Bauder (Gee and Bauder, 1986). The $\mathrm{pH}$ and EC of soil samples was measured in the saturation extract by a pH and EC meter (McLean, 1982; Rhoades, 1996). In addition, $\mathrm{pH}$ and EC of water samples was measured directly by a pH and EC meter (Tüzüner, 1990). Organic matter was determined by using Walkley- Black method (Nelson and Sommers, 1982). The $\mathrm{CaCO}_{3}$ content was measured with a Scheibler calcimeter after addition of dilute acid to the samples (Nelson and Sommers, 1982). The contents of $\mathrm{Fe}, \mathrm{Zn}, \mathrm{Cu}, \mathrm{Mn}, \mathrm{Ni}$ and $\mathrm{Cr}$ extractable by DTPA in the soil were determined as described by Lindsay and Norwel 1987. In addition, the $\mathrm{Pb}$ content was determined by the ammonium acetate method. The total $\mathrm{Fe}, \mathrm{Cu}, \mathrm{Zn} \mathrm{Mn}, \mathrm{Ni}, \mathrm{Cr}$ and $\mathrm{Pb}$ contents of plant samples were measured as described by Kaçar and inal (Kaçar nad İnal, 2010).

\section{Results}

There is no doubt that evaluating ecological conditions that affect plants on a GR and in a pot on a conventional roof is not exactly the same thing as the conventional one can could warm up faster and more intensively, which probably makes the conditions a bit more challenging. However, because all the plants in the research area was in the same conditions and because performances of the plants in harder conditions are important while rooftops are knowns as tough habitats, this micro climatic situation was ignored. The propagation rates of the Sedum species and the chemical content of the plants are the two most important parameters in the evaluation of the effect of the use of GW as the irrigation water on herbal life in GRs, which was the starting point of this study as well. Thus, the analyses for each pot was carried out by considering these two parameters and the results are given below (Table 2).

According to the field measurements, the highest coverage $(67.622 \%)$ was observed in the trial with N-DPGWS irrigation, while the lowest coverage (34.376\%) was observed in the N-I trial. As for the case of Sedum species-specific coverage, the Sedum album species irrigated with N-D.PGWS had the highest cover rate $(60.922 \%)$, while the lowest cover rate $(12.830 \%)$ was observed in the Sedum sediforme species irrigated with TW (Figure 2).

Wild weed coverage ratio was calculated by comparing it with the whole plant coverage within the $5 \mathrm{~cm}-5 \mathrm{~cm}$ grids on each pot. The comparison of the total cover rates with the differences between the cover rates of the Sedum species revealed that the trial with the TW irrigated Sedum sediforme species had the highest wild weed content $(47.786 \%)$, while the trial with the N-D.PGWS irrigated Sedum album species had the lowest wild weed content (6.7\%) (Figure 3). 
Table 2. The soil, plant, and water analysis results with respect to the irrigation types

\begin{tabular}{|c|c|c|c|c|c|c|c|c|}
\hline & \multicolumn{2}{|c|}{ N-I } & \multicolumn{2}{|c|}{ TW } & \multicolumn{2}{|c|}{ 50\%-D.PGWS } & \multicolumn{2}{|c|}{ N-D.PGWS } \\
\hline & $\begin{array}{l}\text { Sedum } \\
\text { album }\end{array}$ & $\begin{array}{c}\text { Sedum } \\
\text { sediforme }\end{array}$ & $\begin{array}{l}\text { Sedum } \\
\text { album }\end{array}$ & $\begin{array}{c}\text { Sedum } \\
\text { sediforme }\end{array}$ & $\begin{array}{l}\text { Sedum } \\
\text { album }\end{array}$ & $\begin{array}{c}\text { Sedum } \\
\text { sediforme }\end{array}$ & $\begin{array}{l}\text { Sedum } \\
\text { album }\end{array}$ & $\begin{array}{c}\text { Sedum } \\
\text { sediforme }\end{array}$ \\
\hline Total Coverage $(\%)$ & 45,608 & 34,376 & 65,086 & 60,616 & 61,900 & 50,662 & 67,622 & 52,112 \\
\hline Sedum Coverage $(\%)$ & 36,940 & 15,886 & 19,124 & 12,830 & 38,546 & 33,506 & 60,922 & 24,350 \\
\hline $\mathrm{Fe}^{*}(\mathrm{ppm})$ & 16,639 & 16,569 & 16,986 & 17,640 & 10,353 & 16,401 & 16,807 & 19,257 \\
\hline $\mathrm{Cu}^{*}(\mathrm{ppm})$ & 0,476 & 0,511 & 0,651 & 0,686 & 0,357 & 0,504 & 0,483 & 0,952 \\
\hline $\mathrm{Mn} *(\mathrm{ppm})$ & 10,948 & 12,999 & 1,323 & 1,358 & 6,636 & 10,871 & 10,647 & 1,568 \\
\hline $\mathrm{Zn} *(\mathrm{ppm})$ & 1,253 & 1,477 & 12,341 & 12,509 & 1,204 & 1,344 & 1,512 & 9,023 \\
\hline $\mathrm{Ni}^{*}(\mathrm{ppm})$ & 0,266 & 0,490 & 0,385 & 0,238 & 0,378 & 0,497 & 0,420 & 0,455 \\
\hline $\mathrm{Cr}^{*}(\mathrm{ppm})$ & 8,890 & 1,267 & 9,982 & 10,052 & 13,391 & 7,462 & 12,810 & 11,396 \\
\hline $\mathrm{Pb}^{*}(\mathrm{ppm})$ & 2,400 & 2,330 & 2,400 & 2,330 & 2,320 & 2,360 & 2,550 & 2,620 \\
\hline O. Matter (\%) & 1,550 & 1,570 & 1,580 & 1,620 & 1,650 & 1,630 & 1,490 & 1,470 \\
\hline $\mathrm{Ph}^{*}$ & 6,630 & 7,000 & 6,780 & 6,940 & 7,000 & 7,130 & 7,220 & 6,970 \\
\hline $\mathrm{EC}^{*}(\mu \mathrm{S} / \mathrm{cm})$ & 152,900 & 164,500 & 152,200 & 165,300 & 189,500 & 196,800 & 159,500 & 148,000 \\
\hline $\mathrm{CaCO}_{3} \mathrm{~S}(\%)$ & 0,840 & 0,880 & 0,840 & 0,850 & 0,920 & 0,330 & 1,050 & 0,760 \\
\hline $\mathrm{Fe}^{* *}(\mathrm{ppm})$ & 833,000 & 1693,500 & 1512,500 & 1053,500 & 172,550 & 1687,500 & 150,100 & 1028,500 \\
\hline $\mathrm{Cu}^{* *}(\mathrm{ppm})$ & 43,450 & 78,450 & 19,550 & 45,200 & 19,850 & 65,800 & 16,150 & 43,400 \\
\hline $\mathrm{Mn} * *(\mathrm{ppm})$ & 4,250 & 11,300 & 5,800 & 6,950 & 3,850 & 9,950 & 3,900 & 8,900 \\
\hline $\mathrm{Zn}^{* *}(\mathrm{ppm})$ & 18,900 & 55,200 & 21,200 & 41,300 & 16,650 & 38,750 & 9,300 & 59,700 \\
\hline $\mathrm{Ni}^{* *}(\mathrm{ppm})$ & 6,500 & 1,800 & 6,600 & 9,950 & 5,350 & 18,550 & 7,250 & 1,900 \\
\hline $\mathrm{Cr}^{* *}(\mathrm{ppm})$ & 134,000 & 125,550 & 94,200 & 134,900 & 14,350 & 20,500 & 56,750 & 115,300 \\
\hline $\mathrm{Pb}^{* *}(\mathrm{ppm})$ & 0,880 & 0,890 & 1,010 & 0,900 & 0,960 & 1,020 & 0,110 & 1,140 \\
\hline $\mathrm{Fe}^{* * *}(\mathrm{ppm})$ & \multicolumn{2}{|r|}{ - } & \multicolumn{2}{|c|}{0,23} & \multicolumn{2}{|c|}{ - } & \multicolumn{2}{|c|}{1,05} \\
\hline $\mathrm{Cu} * * *(\mathrm{ppm})$ & \multicolumn{2}{|r|}{-} & \multicolumn{2}{|c|}{0,09} & \multicolumn{2}{|c|}{7,000} & \multicolumn{2}{|c|}{7,65} \\
\hline $\mathrm{Mn} * * *(\mathrm{ppm})$ & & - & \multicolumn{2}{|c|}{0,04} & \multicolumn{2}{|c|}{1,700} & \multicolumn{2}{|c|}{1,9} \\
\hline $\mathrm{Zn} * * *(\mathrm{ppm})$ & & - & \multicolumn{2}{|c|}{-} & \multicolumn{2}{|c|}{-} & \multicolumn{2}{|r|}{-} \\
\hline $\mathrm{Ni} * * *(\mathrm{ppm})$ & & - & \multicolumn{2}{|c|}{-} & \multicolumn{2}{|c|}{-} & \multicolumn{2}{|r|}{-} \\
\hline $\mathrm{Cr} * * *(\mathrm{ppm})$ & & - & \multicolumn{2}{|c|}{0,25} & \multicolumn{2}{|c|}{125,000} & \multicolumn{2}{|c|}{121,3} \\
\hline $\mathrm{Pb}^{* * *}(\mathrm{ppm})$ & & - & \multicolumn{2}{|c|}{0,02} & \multicolumn{2}{|c|}{0,470} & \multicolumn{2}{|c|}{0,59} \\
\hline $\mathrm{Ph} * * *$ & & - & \multicolumn{2}{|c|}{6,952} & \multicolumn{2}{|c|}{7,130} & & 7,27 \\
\hline $\mathrm{EC}^{* * *}(\mu \mathrm{S} / \mathrm{cm})$ & & - & 17 & 3,22 & 102 & 1,000 & & 1098 \\
\hline
\end{tabular}

*: Soil analysis; **: Plant analysis; ***: Water analysis 


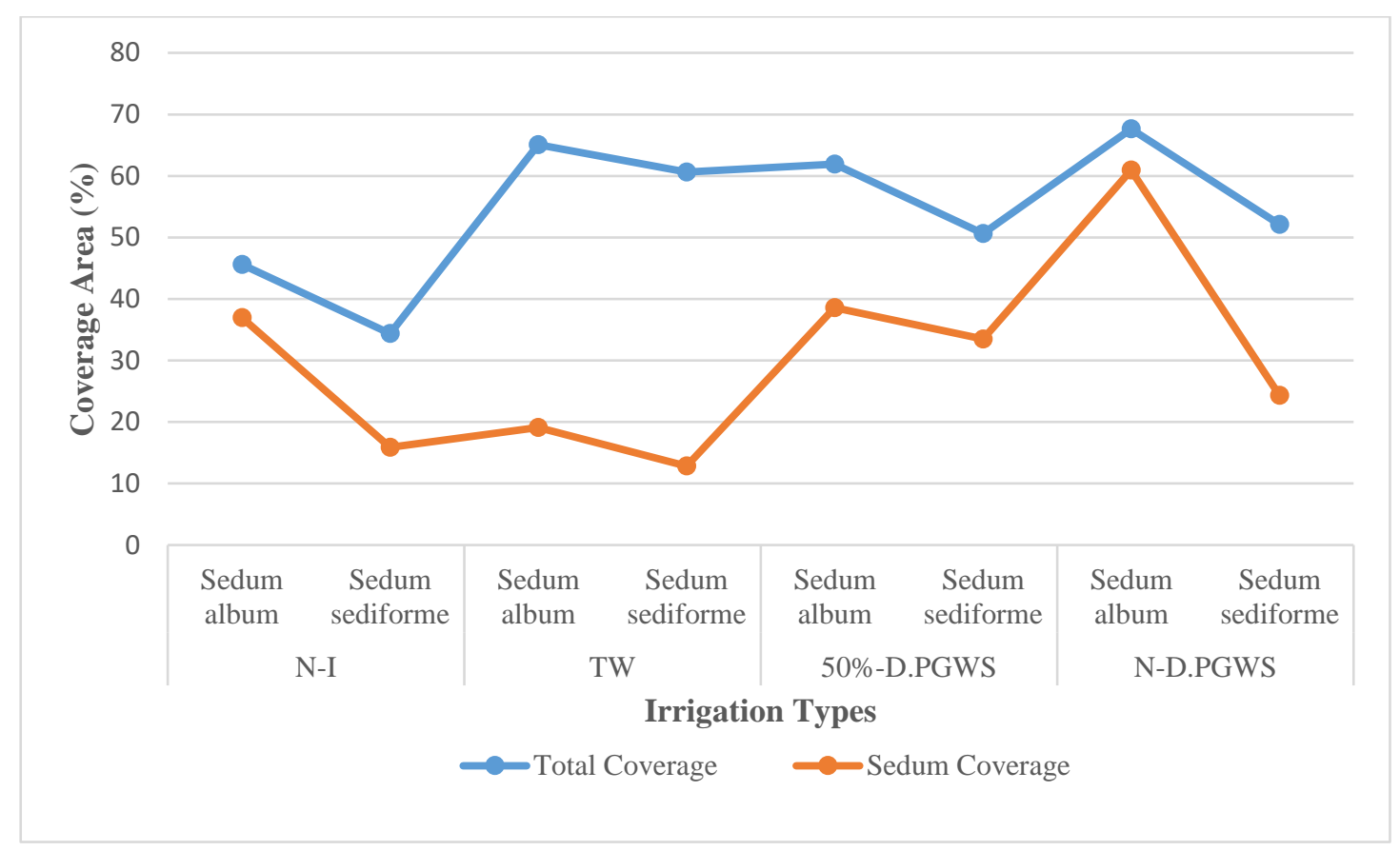

Figure 2. The cover rates with respect to the irrigation types

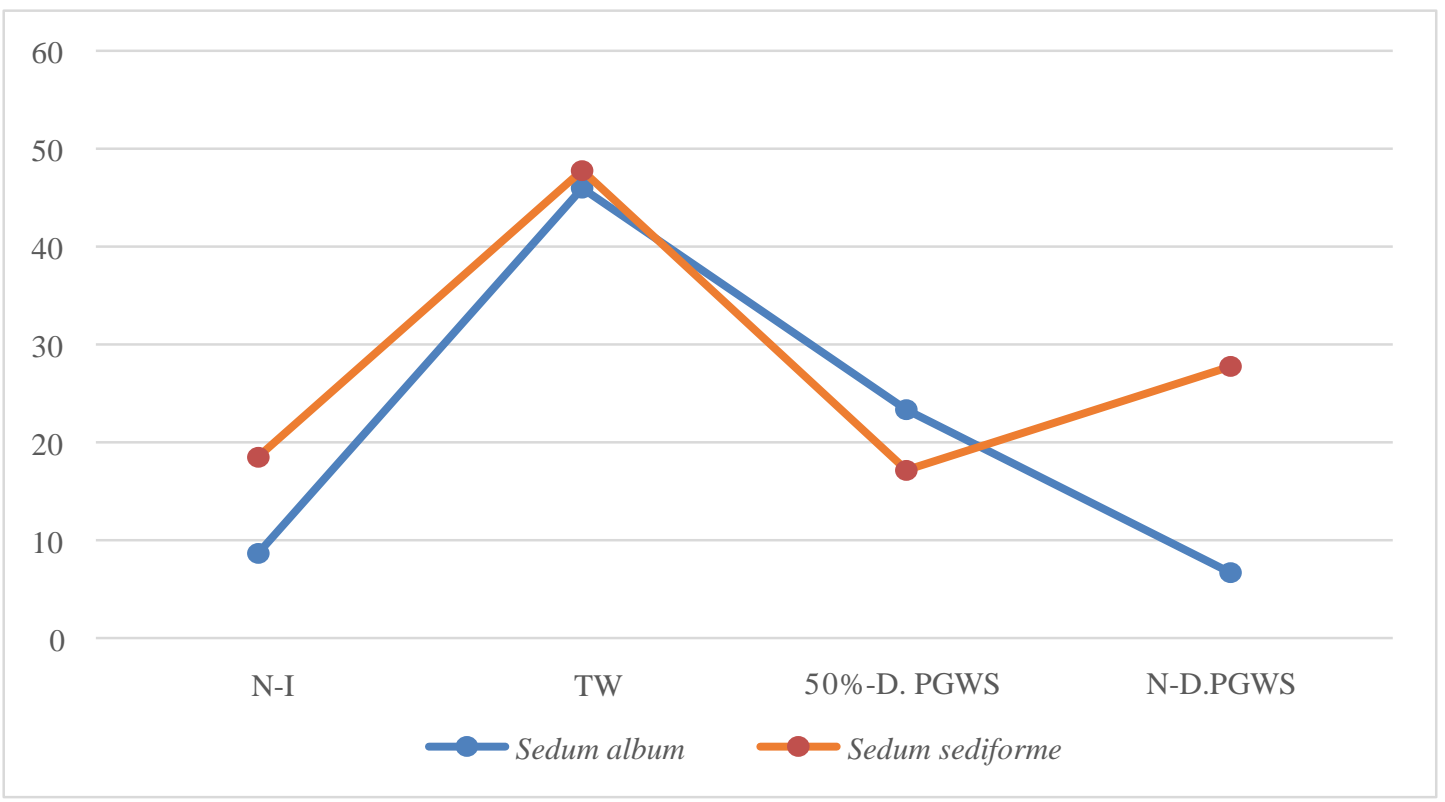

Figure 3. The wild weed content of the trial pots with respect to the irrigation types

\section{Conclusion and Recommendations}

Making a classification according to the irrigation types, non-irrigated plants were coded as ' $\mathrm{N}-\mathrm{I}$ ', the plants irrigated with tap water were codes as ' $\mathrm{TW}$ ', the plants irrigated with $50 \%$ diluted water were coded as ' $50 \%$-D.PGWS', and the plants irrigated with nondiluted water were coded as 'N-D.PGWS' while, in terms of Sedum species, Sedum album was coded as 'S. Al.' and Sedum sediforme as 'S. Sed.' and recorded into the database. 
In Table 3, in a comparison between the irrigation type and the cover density of Sedum species, it is seen that the highest average value was obtained in N-D.PGWS ( $S$. al.) group $(\mathrm{x}=60,400)$. This rate was followed by $50 \%$-D. PGWS $(S . a l).(\mathrm{x}=38,000), \mathrm{N}-\mathrm{I}(S . a l$. $(\mathrm{x}=36,600), \mathrm{N}-\mathrm{I}($ S. sed.) $(\mathrm{x}=34,000), 50 \%$-D. PGWS (S. sed.) $(\mathrm{x}=33,000)$, N-D.PGWS (S. sed.) $(\mathrm{x}=23,800)$ and TW (S. al. $)(\mathrm{x}=18,600)$. The irrigation type that Sedum species exhibited the lowest propagation was determined to be TW (S. sed.) $(\mathrm{x}=12,400)$.

Table 3. Results of the One-way Analysis of Variance performed to determine the differences between the coverage area of Sedum species according to the irrigation variable

\begin{tabular}{|c|c|c|c|c|c|c|}
\hline & Irrigation Type & $\mathbf{N}$ & $\mathbf{X}$ & SE & $\mathbf{F}$ & Sig. \\
\hline \multirow{8}{*}{$\begin{array}{c}\text { Coverage Area of Sedum } \\
\text { Types }\end{array}$} & N-I (S. sed.) & 10 & 34,000 & 5,568 & \multirow{8}{*}{6,767} & \multirow{8}{*}{0,000} \\
\hline & N-I (S. al.) & 10 & 36,600 & 2,337 & & \\
\hline & TW (S. sed.) & 10 & 12,400 & 3,385 & & \\
\hline & TW (S.al.) & 10 & 18,600 & 5,354 & & \\
\hline & 50\%-D. PGWS (S. sed.) & 10 & 33,000 & 5,797 & & \\
\hline & 50\%-D. PGWS (S. al.) & 10 & 38,000 & 9,338 & & \\
\hline & N-D.PGWS (S. sed.) & 10 & 23,800 & 1,497 & & \\
\hline & N-D.PGWS (S. $a l)$. & 10 & 60,400 & 7,325 & & \\
\hline
\end{tabular}

To determine if different irrigation types have a significant effect on the propagation types of Sedum species, the statistical analysis One-Way Anova test was utilized. As a result of the statistical analysis, a statistically significant difference was determined $\mathrm{F}=6.767$, $(\mathrm{p}<0.05)$. To determine the source of the difference, the Tukey test of the Post Hoc tests was utilized. The direction of the difference was determined to be N-D.PGWS (S. sed.)-TW (S. sed.).

To examine whether different irrigation types significantly affect the overall propagation rates, One-Way Anova test was used (Table 4). As a result of the statistical analysis, no statistically significant differences were found. In the study, for the Sedum species used to determine the performance of GW in GRs, it was determined that irrigation with GW had a positive effect on the coverage area.

Table 4. One-way ANOVA results to determine the differences between total coverage area according to irrigation variables

\begin{tabular}{|c|c|c|c|c|c|c|}
\hline & Irrigation Type & $\mathbf{N}$ & $\mathbf{X}$ & $\mathbf{S E}$ & $\mathbf{F}$ & Sig. \\
\hline \multirow{8}{*}{ Total Coverage Area } & N-I (S. sed.) & 10 & 34,376 & 5,590 & \multirow{8}{*}{2,147} & \multirow{8}{*}{0,67} \\
\hline & $\mathrm{N}-\mathrm{I}(S . a l)$. & 10 & 45,590 & 4,784 & & \\
\hline & TW (S. sed.) & 10 & 60,616 & 7,362 & & \\
\hline & TW (S.al.) & 10 & 65,186 & 9,575 & & \\
\hline & 50\%-D. PGWS (S. sed.) & 10 & 50,662 & 4,732 & & \\
\hline & 50\%-D. PGWS (S. al.) & 10 & 61,900 & 10,902 & & \\
\hline & N-D.PGWS (S. sed.) & 10 & 52,112 & 8,630 & & \\
\hline & N-D.PGWS (S.al.) & 10 & 67,622 & 7,361 & & \\
\hline
\end{tabular}

When the same analysis was performed for the wild weeds in the pots and all the areas covered green, it was seen that the irrigation type had no effect on the propagation area. GRs are known as surfaces where living conditions are not so easy due to many conditions including solar energy and intense winds that they are exposed to. Therefore, certain 
species with high resistance to these challenging conditions are very popular in both scientific researches and practice studies in this field. Sedum album and Sedum sediforme are two of the most known species of these species and are selected as the materials in this research. Numerous wild weeds that came to the area after these species were brought to the area, since they can easily adapt to and tolerate these difficult conditions, were found abundantly even in the N-I trial and, therefore, inhibited the effect of the green area associated with irrigation. At the point, the best answers to the question "So, why are Sedum species primarily preferred for the GRs?" are that they are always green compared to these wild species, they cover the area in a more compact way and they form a more aesthetic and successful layer in terms of thermal insulation. In addition, the contribution of these natural Sedum species to the biological diversity and the effect of feeding the wild life is inherently higher.

Examining the correlation tests, it was determined that the propagation of Sedum species is inversely proportional to $\mathrm{Fe}(\mathrm{Fe} * *)$ and $\mathrm{Pb}(\mathrm{Pb} * *)$ elements in the plant (Table 5).

Table 5. Sedum cover density correlation analysis

\begin{tabular}{c|c|c|c}
\hline \multicolumn{2}{l|}{} & $\mathbf{F e}^{* *}$ & $\mathbf{P b}^{* *}$ \\
\hline & Pearson Correlation &,$- 716^{*}$ &,$- 745^{*}$ \\
Sedum Coverage & Sig. (2-tailed) &, 046 &, 034 \\
& $\mathrm{~N}$ & 8 & 8 \\
\hline
\end{tabular}

Iron has an important feature since it can easily form clay with organic complexes in soil and plants. Therefore, iron can become soluble in the upper layers of the overly washed and low-drainage soils, and it adheres to the lower soil layer (Karaman, 2012). In the nutrient environments such as the roof gardens where the depth of the soil is low, Fe can be transported to the plant via the plant roots even if it adheres to the lower soil.

Excessive Fe intake forms a toxic effect in plants. Tanning is the most important example of this toxic effect in plant leaves. This is observed when Fe content in leaves is $700 \mathrm{mg} / \mathrm{kg}$ (Anonymous, 2005; Yamauchi, 1989). Tanning in iron toxicity results from oxidized polyphenols (Peng and Yamauchi, 1993). K application can be carried out to eliminate iron toxicity. In this case, $\mathrm{K}$ both reduces the $\mathrm{Fe}^{2+}$ uptake and increases oxidative potential of roots (Güneş et al., 2000).

Lead is not absolutely required for plants, but it is found in the soil at a dose of 15$40 \mathrm{ppm}$. It is potentially dangerous for human health when it exceeds 300 ppm (Özkan, 2017; Kaçar et al., 2013; Dürüst et al., 2004). Lead affects the plant water regime due to its negative effects on cell turgor and cell wall stability, and its reducing effect on stoma movements and leaf area. Also, it reduces the uptake of cations and anions since it is held by the roots and it reduces root development, affecting nutrient uptake (Tao et al., 2007; Sharma, 2005).

Examining the propagation of the species in total, it was determined that the cover density was directly proportional to $\mathrm{Cr}(\mathrm{Cr} *)$ in the soil and $\mathrm{pH}$ value $(\mathrm{pH} * * *)$ of the irrigation water and inversely proportional to $\mathrm{Cu}(\mathrm{Cu} * *)$ in the plant (Table 6). 
Table 6. Total cover density correlation analysis

\begin{tabular}{c|c|c|c|c}
\hline \multicolumn{2}{l|}{} & $\mathbf{C r}$ & $\mathbf{C u}$ & $\mathbf{P h}^{* * * *}$ \\
\hline \multirow{3}{*}{ Total Coverage } & Pearson Correlation &, $850^{* *}$ &,$- 765^{*}$ &, $807^{*}$ \\
& Sig. (2-tailed) &, 008 &, 027 &, 015 \\
& $\mathrm{~N}$ & 8 & 8 & 8 \\
\hline
\end{tabular}

Chrome is naturally found in soils in amounts ranging between $5-100 \mathrm{mg} / \mathrm{kg}$ (Asri and Sönmez, 2006; Özbek et al., 1995). The first physiological process affected by the toxic chrome levels in plants is seed germination (Knezevic et al., 2009; Jain et al. 2000). Although chrome reportedly inhibits the development of roots through obstructing cellular division in roots and root growth and thus reduces plant growth and development through decreased water and nutrient intake from soils (Khan et al., 2000), the statistical analysis of the results obtained with the experiment installed in this study showed that the total cover density increased with increased chrome levels in soils.

The toxicity level of copper differ among plants (Knezevic, 2009; Robson and Reuter 1981; Hodenberg and Finck, 1975). The first symptoms of copper toxicity in coppersensitive plants include decreased root growth, damaged plasms and membranes, and release of potassium (K) ions (De Vos et al., 1991; Baker and Walker, 1989). The decreases in the indole-3-acetic acid (IAA) oxidase activity in plants due to exposure to high $\mathrm{Cu}$ concentrations lead to certain changes such as reduced root growth and lateral root formation (Karaman, 2012).

The $\mathrm{pH}$ of the irrigation waters directly or indirectly affects various physical, chemical, and biological phenomena that occur in soils. There is a close relationship between soil reactions and soil biota; for example, fungi are more active at $\mathrm{pH} 4-5$, while bacteria are more active at $\mathrm{pH}$ 6-8. Moreover, $\mathrm{pH}$ levels also play an important role in the availability of the nutrients found in soils to vegetables. The most suitable $\mathrm{pH}$ range for nitrogen, phosphorus, and potassium intake by vegetables is between 6.5 and 7.5. At $\mathrm{pH}$ levels below 6.0, phosphorus bonds with $\mathrm{Al}$ and at $\mathrm{pH}$ levels above 7.5, phosphorus bonds with $\mathrm{Ca}$, which obstructs its intake by plants. $\mathrm{Al}$ and $\mathrm{Mn}$ have toxic effects on plants at $\mathrm{pH}$ levels below 5.0, while at $\mathrm{pH}$ levels below 7.5, microelements such as $\mathrm{Fe}, \mathrm{Cu}, \mathrm{Zn}, \mathrm{Mn}$ convert to a non-soluble form and their availability to plants significantly decreases (Url $1 ; 2018)$. As a result of the statistical analyses, it was seen that the $\mathrm{Cu}$ taken from the soil was inversely proportional to the plant growth. It is expected that the $\mathrm{pH}$ of the irrigation water will increase the plant propagation since the $\mathrm{pH}$ of the water makes the element of $\mathrm{Cu}$ insoluble and decrease its intake by the plants, preventing the toxic effect of $\mathrm{Cu}$.

Evaluating the study as a whole, it was seen that there was a significant difference between irrigation and non-irrigation of Sedum, one of the most popular GR plants, in terms of the roof surfaces they cover. In addition, since clean water is one of the most valuable items in the world, considering GW as an alternative irrigation method, it was seen that this usable waste water can decrease, even eliminate, the use of important and expensive TW. It was also seen that the use of GW provides more positive effects on the plant growth compared to that of the TW. In this sense, by using GW in GRs, it would be possible to achieve both economical and ecologically more favorable results, by both reducing water consumption and providing positive effects on plant growth. Moreover, it is also clear that utilizing this waste water will reduce the irrigation costs of the GR 
systems and consider the GR as a more sustainable and economic alternative in the long run, thus becoming more widespread and having an impact on urban sustainability. Yalçınalp at al. (2018) has stated that the use of the industrial system required for GW use would prove to meet the GR cost in the long run and that greywater should be used as irrigation water. Despite its ecological and economic benefits, the incentives and scientific studies on using GW in the irrigation for the widespread use of GR systems, which are still not widespread as it should be, will greatly contribute to making the world a more sustainable place.

Acknowledgements. This research was designed as a part of a master thesis of which the title is "Performance of Greywater Irrigation on Two Sedum Species", which was supervised by Emrah Yalçınalp.

\section{REFERENCES}

[1] Anonymous (2013a): Seçilmiş Göstergelerle Trabzon - Turkish Statistical Institute Printing Division: Ankara, Turkey.

[2] Anonymous (2013b): Address Based Population Registration System Results. - Turkish Statistical Institute Printing Division: Ankara, Turkey

[3] Anonymous (2005): Resmi Gazete. - Toprak Kirliliğinin Kontrolü Yönetmeliği. Sayı: 25831, Tarih: 31.05.2005.

[4] Antonopoulou, G., Kirkou, A., Stasinakis, A. S. (2013): Quantitative And Qualitative Greywater Characterization In Greek Households And Investigation of Their Treatment Using Physicochemical Methods. - Science of the Total Environment 454: 426-432.

[5] Asri, F. Ö., Sönmez, S. (2006): Ağır Metal Toksisitesinin Bitki Metabolizması Üzerine Etkileri - Derim 23(2): 36-45.

[6] Baker, A. J. M., Walker, P. L. (1989): Physological Response of the Plants to Heavy Metals and the Quantification of Tolerance and Toxicity - Chemical Speciation \& Bioavailability 1(1): 7-17.

[7] Benami, M., Gross, A., Herzberg, M., Orlofsky, E., Vonshak, A., Gillor, O. (2013): Assessment of Pathogenic Bacteria in Treated Greywater and Irrigated Soils. - Science of The Total Environment 458: 298-302.

[8] Davis, P.H. (1965): Flora of Turkey and the East Aegean Islands - Aldine Publishing Co.: New York, NY, USA; Volume 1.

[9] Davis, P.H. (1985): Flora of Turkey and the East Aegean Islands, vol. 1-9 - Aldine Publishing Co.: New York, NY, USA, 1985; Volume 9.

[10] De Vos, C. H. R., Schat, H., de Waal, M. A., M., Woojis, R., Ernst, W. H. O. (1991): Increased Resistance of Copper Induces Damage of the Roots Cell Plasmalemma in Copper Tolerant Silene cucubalus - Physiologia Plantarum 82(4): 523-528.

[11] Dürüst, N., Dürüst, Y., Tuğrun, D., Zengin, M. (2004): Heavy Metal Contents of Pinus Radiata Trees of Izmit (Turkey) - Asian Journal of Chemistry 16(2): 1129-1134.

[12] Eriksson, E. (2002): Potentiel and Problems Related to Refuse of Water in Households Phd. Thesis, Environment and Resources DTUi Technical University of Denmark.

[13] Eriksson, E., Auffarth, K., Eilersen, A. M., Henze, M., Ledin, A. (2003): Household Chemicals and Personal Care Products as Sources for Xenobiotic Organiz Compounds in Grey Wastewater - Water Search 29(2): 135-146.

[14] Friedler, E., Hadari, M. (2006): Economic Feasibility of On-Site Grey Water Reuse in Multi-Storey Buildings - Desalination 190(1): 221-234.

[15] Gee, G. W., Bauder, J. W. (1986): Particle size analysis - In: Klute, A. (ed.). Method of soil analysis, part 1 No9, ASA Inc, SSSA Inc. Madison, WI: 383-409. 
[16] Güneş, A., Alparslan, M., İnal, A. (2000): Bitki Besleme ve Gübreleme - A.Ü. Ziraat Fakültesi Yayınları, Ankara.

[17] Hodenberg, V. A., Finck, A. (1975): Ermittlung von toxizitaitsgrenzwertwn Fur Zink, Kupfer und Blei in Hafer und Rotklee. - Journal of Plant Nutrition and Soil Science 138(45): 489-503.

[18] Illan, R. V. (2011): Cultivo de Hortensia en Maceta Bajo Agua Residual Depurada Salina: Eficacia del Lavado con Agua Buena - Departamento De Producción Vegetal Escuela Técnica Superior de Ingeniería Agronómica, Unıversidad Politécnica De Cartagena.

[19] Jain, R., Srivastava, S., Madan, V. K. (2000): Influence of Chromium on Growth and Cell Division of Sugarcane - Indian Journal of Plant Physiology 5: 228-231.

[20] Jefferson, B., Laine, A., Parsons, S., Stephenson, T., Judd, S. (1999): Technologies for Domestic wastewater Recycling - Urban Water 1(4): 285-292.

[21] Kacar, B., İnal, A. (2010): Plant analysis, 2nd ed. - Nobel Academic Publishing, Ankara.

[22] Kacar, B., Katkat, V., Öztürk, Ş. (2013): Vegetable Physiology. - Nobel Akademik Yayıncılık Eğitim ve Danışmanlık Ltd. Ști. Ankara. Türkiye.

[23] Karaman, M. R. (2012): Bitki Besleme "Sağlıklı Bitki, Sağlıklı Üretim" - Gübretaş Rehber Kitapları Dizisi: 2, Dumat Ofset, Bask1: 1, Ankara.

[24] Khan, A. G., Kuek, C., Chaudhry, T. M., Khoo, C. S., Heyes, W. J., (2000): Role of Plants, Mycorrhizae and Phytochelators in Heavy Metal Contaminated Land Remediation Chemosphere 41: 197-207.

[25] Knezevic, M., Stankovic, D., Krstic, B., Nikolic, M. S., Dragica, V. (2009): Concentrations of Heavy Metals in Soil and Leaves of Plant Species Paulownia Elongata S.Y.Hu and Paulownia Fortunei Hemsl. - African Journal of Biotechnology 8(20): 5422-5429.

[26] Li, Z., Gulyas, H., Jahn, M., Gajurel, D. R., Otterpohl, R. (2003): Grey Water Treatment by Constructed Wetland in Combination with TiO2-Based Photocatalytic Oxidation for Sub-Urban and Rural Areas Without Sewer System - Water Science and Technology 48(11): 101-106.

[27] Li, F., Wichmann, K., Otterpohl, R. (2009): Rewiev of the Technological Approaches for Grey Water Treatment and Reuses - Science of the Total Environment 407: 3439-3449.

[28] Lindsay, W. L., Norvell, W. A., (1978): Development of a DTPA soil test for zinc, iron, manganese, and copper. - Soil Sci Soc Am J 42:421-428.

[29] McLean, E. O. (1982): Soil pH and lime requirement. - In: Page, A. L., Miller, R. H., Keeney, D. R. (eds) Methods of Soil Analysis, part 2, Chemical and Microbiological Properties, 2nd ed. Agronomy Monograph 9, American Society of Agronomy Inc., Madison, WI: 199-224.

[30] Mohamed, R. M. S. R., Kassim, A. H. M., Anda, M., Dallas, S. (2013): A Monitoring of Environmental Effects From Household Greywater Reuse for Garden Irrigation. Environmental Monitoring and Assessment 185(10): 8473-8488.

[31] Morel, A., Diener, S., (2006): Grey Water Management in Low and Middle-Income Countries - Water and Sanitation in Developing Countries, Swiss Federal Institute of Aquatic Science and Technology.

[32] Negahban-Azar, M., Sharvelle, S. E., Stromberger, M. E., Olson, C., Roesner, L. A. (2012): Fate of Greywater Constituents After Long-Term Application for Landscape Irrigation. Water, Air \& Soil Pollution 223(8): 4733-4749.

[33] Nelson D. W., Sommers, L. E., (1982): Methods of Soil Analysis, part 2, Chemical and Microbiological Properties, 2nd ed. - In: Page, A. L., Miller, R. H., Keeney, D. R. (eds) Total carbon, organic carbon, and organic matter. Agronomy Monograph 9, American Society of Agronomy Inc., Madison, WI: 181-198, 539-580.

[34] Ottoson, J., Stenström, T. A. (2003): Faecal Contamination of Grey Water and Associated Microbial Risks - Water Research 37(3): 645-655.

[35] Özbek, H., Kaya, Z., Gök, M., Kaptan, H. (1995): Toprak Bilimi. - Çukurova Üniversitesi Ziraat Fakültesi Yayınları, Adana. 
[36] Özkan, A., (2017): Antakya-Cilvegözü Karayolu Etrafındaki Tarım Arazilerinde ve Bitkilerdeki Ağır Metal Kirliliği. - Çukurova Üniversitesi Mühendislik Mimarlık Fakültesi Dergisi 32(3): 9-18.

[37] Peng, X., Yamauchi, M. (1993): Ethylene Production in Rice Bronzing Leaves Induced by Ferrous Iron - Plant Soil 169: 227-234.

[38] Rhoades, J. D. (1996): Methods of Soil Analysis, part 3, Chemical Methods. - In: Sparks, D. L., Page, A. L., Helmke, P. A., Loeppert, R. H., Soltanpour, P. N., Tabatabai, M. A., Johnston, C. T., Sumner, M. E. (eds) Salinity: electrical conductivity and total dissolved solids. Soil Science Society of America Book Series, No. 5, Madison, WI: 417-435.

[39] Robson, A. D., Reuter, D. J. (1981): Diagnosis of Copper Deficiency and Toxicity. - In copper in Soils and Plants, Academic Press, London: 287-312.

[40] Sharma, P., Dubaey, R. S. (2005): Lead Toxicity in Plants - Brazilian Journal of Plant Physiology 17(1): 35-52.

[41] Tao, S. G., Lou, C. Z., Yuan, X. S., Li, W., Ju, Z., Wen, H. L. (2007): Characteristics of Heavy Metal Pollution in Soil and Dust of Urban Parks in Shanghai. - Environmental Science 53: 250-330.

[42] Tüzüner, A. (1990): Toprak ve Su Analiz Laboratuvarları El Kitabı - T.C. Tarım Orman ve Köyişleri Bakanlığı, Köy Hizmetleri Genel Müdürlüğü, Ankara.

[43] URL 1: https://ziraatyapma.blogspot.com.tr/2015/11/toprak-ph-degerinin-etkileri-olcumuve.html (Access on: 02.03.2018)

[44] Yalçınalp, E., Öztürk, A., Bayrak, D. (2018): Konut Ölçeğinde Gri su ve Yeşil Çatı Sistemlerine Ekonomik Etkileri. - Turkish Journal of Agricultural and Natural Sciences 5(1): 71-80.

[45] Yamauchi, N. (1989): Cholorophyll Derivates of Stored Leafy Vegetables. - Journal of the Japanese Society for Cold Preservation 15: 82-86.

[46] Zavala, M. A. L. A., Estrada, E. E. (2016): The Contribution of the Type of Detergent to Domestic Laundry Greywater Composition and Its Effect on Treatment Performance Water 8(5): 214-224. 